\title{
Masquerade, mimicry and crypsis of the polymorphic sea anemone Phyllodiscus semoni and its aggregations in South Sulawesi
}

\author{
Bert W. Hoeksema ${ }^{1,3}$, Andrea L. Crowther ${ }^{1,2}$ \\ ${ }^{1}$ Department of Marine Zoology, Netherlands Centre for Biodiversity Naturalis, PO Box 9517, 2300 RA Leiden, \\ The Netherlands \\ ${ }^{2}$ Department of Ecology and Evolutionary Biology, and the Biodiversity Institute, The University of Kansas, 1200 \\ Sunnyside Ave., Lawrence, KS 66045, USA \\ ${ }^{3}$ E-mail: bert.hoeksema@ncbnaturalis.nl
}

Key words: Actiniaria, Aliciidae, camouflage, Indonesia, morphotype, southern Japan, toxicology

\begin{abstract}
Phyllodiscus semoni is a morphologically variable sea anemone species from the Indo-Pacific with morphotypes ranging from upright and branched to low-lying and rounded. The apparent camouflage strategies of this sea anemone allow it to resemble other species or objects in its environment, such as stony corals, soft corals, seaweeds, or rocky boulders covered by algae, which may help it to avoid recognition by potential predators. Occasionally, it occurs in aggregations that may result from asexual reproduction. A high level of intraspecific morphological variation, including co-occurring aggregations of three different morphotypes, was observed in the Spermonde Archipelago off Makassar, South Sulawesi, Indonesia. The co-occurrence of aggregations with different morphotypes suggests that Phyllodiscus is a highly polymorphic monospecific genus. Sea anemones of this genus are not frequently encountered at other localities and the number of morphotypes seems large. Therefore, it is unlikely that we are dealing with more than one species that are all concentrated in a single area. Phyllodiscus sea anemones are considered dangerous to humans because their nematocysts contain highly toxic venoms that may inflict harmful stings. Therefore they are the subject of recent toxicological studies. The present paper aims to assist in the recognition of these highly variable hazardous animals and to discuss the appearance of their aggregations.
\end{abstract}

\section{Contents}

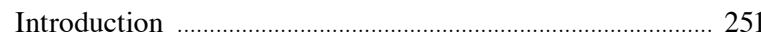

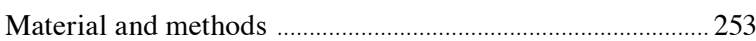

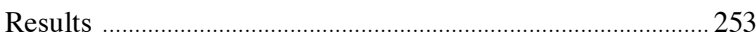

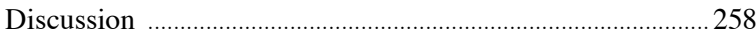

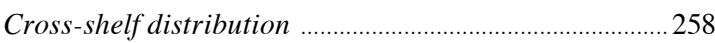

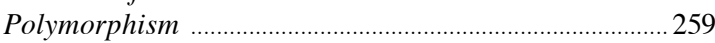

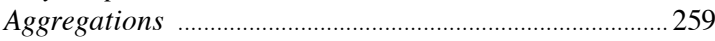

Co-occurrence of morphotypes in aggregations ............. 261

Misidentification of venomous sea anemones .................. 261

Distinguishing mimics from models ..................................2263

Application of multiple defense strategies ........................263

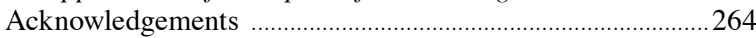

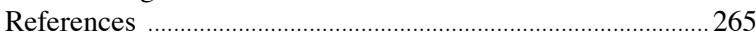

\section{Introduction}

Phyllodiscus semoni Kwietniewski, 1897 (Actiniaria: Aliciidae) is a species of sea anemone found on coral reefs in the Indo-Pacific, which can inflict harmful stings to humans (Den Hartog, 1997; Fosså and Nilsen, 1998). Phyllodiscus semoni can occur as individuals or in aggregations (Strack, 1993) that attach to rock or dead coral and are able to move over the substrate. In this way, they differ from some other stinging sea anemones, such as sand-dwelling actiniarians of the genus Actinodendron de Blainville, 1830, which live partly buried and can completely retract into the sediment. Much morphological variation exists within $P$. semoni, but this has not been widely or thoroughly reported, which is why this species is difficult to recognise and has been confused with other sea anemone species, such as Actinodendron plumosum Haddon, 1898 (Den Hartog, 1997; Fosså and Nilsen, 1998), other cnidarians, algae, or inanimate objects found in the environment. Phyllodiscus semoni is not known from many localities and the range of morphotypes seems so large (with new varieties still being discovered in the field), that it is unlikely that we are dealing with more than one species. The collected material is under investigation for possible genetic differences and morphological variation to indicate different species, but no evidence has been found so far (Crowther and Hoeksema, in prep).

The original descriptions of Phyllodiscus Kwietniewski, 1897, and P. semoni were based on a sole museum specimen collected from Ambon, Indonesia (Kwietniewski, 1897, 1898). The description lacks information relating to the natural history and habitat of this species, as the author presumably never saw the sea anemone alive nor visited the site where it was 


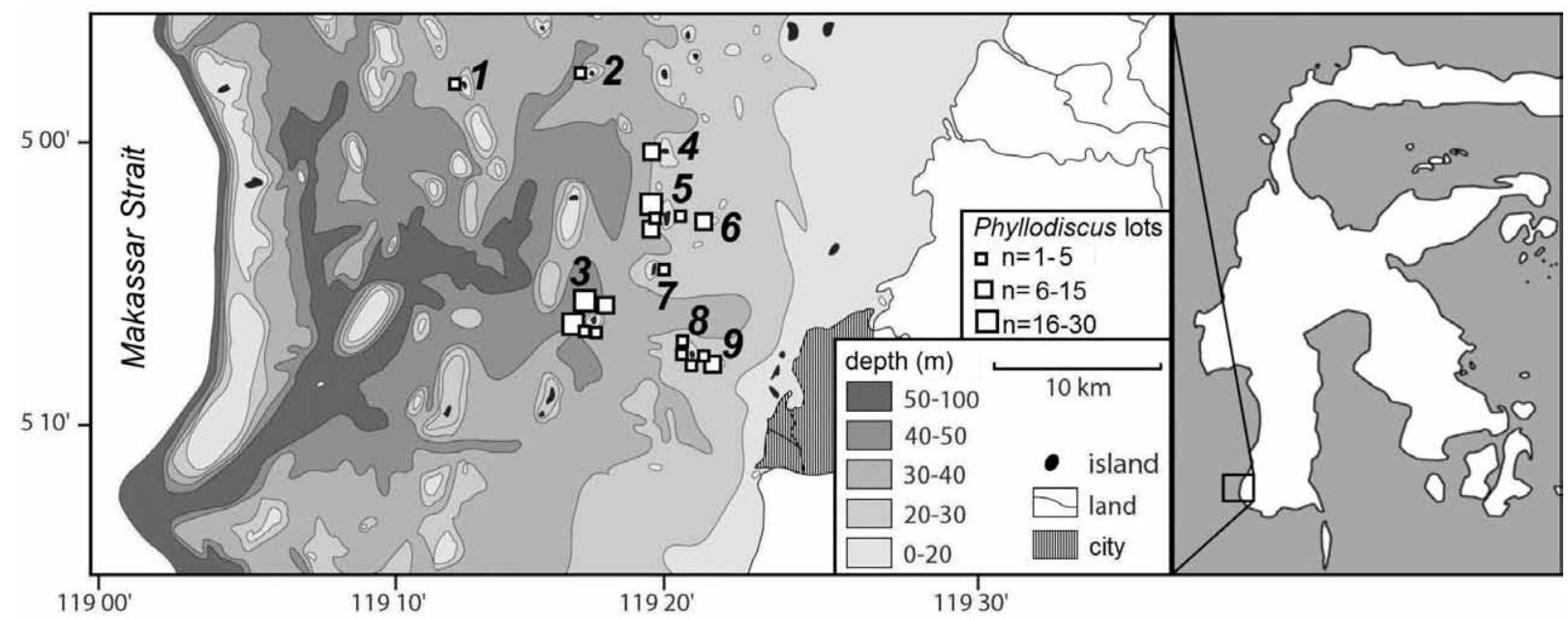

Fig. 1. Map of the Spermonde Archipelago, off Makassar city (hatched pattern), South Sulawesi, where Phyllodiscus semoni was observed. Boxes indicate total numbers of observations per site varying from 1 to 30 in the years 1994-1998 (categories n = 1-5, 6-15, 16-30). One observation may concern one or more individuals of a particular morphotype. Reefs: $1=$ Lumu Lumu, $2=$ Pulau Badi, $3=$ Kudingareng Keke, $4=$ Bone Batang, 5 = Barrang Lompo, $6=$ Bone Lola, $7=$ Barrang Caddi, $8=$ Samalona, $9=$ Bone Baku.

collected. Despite the fact that more recently this species has been recorded in field guides of the Indo-Pacific (e.g. Gosliner et al., 1996; Williamson et al., 1996; Coleman, 2000; Halstead, 2000; Erhardt and Knop, 2005; Bergbauer et al., 2007) and is the subject of toxicological studies (e.g. Mizuno et al., 2000, 2007; Nagai et al., 2002a, b; Nagata et al., 2006; Satoh et al., 2007), there is still very little published information about the natural history of this species.

Phyllodiscus has been reported to occur as solitary individuals or in aggregations; we use the term aggregation to refer to a dense group of multiple individuals of identical morphotype and colouration at the same locality. Because of the high density of individuals of the same morphotype, we assume that Phyllodiscus uses asexual reproduction, and that therefore an aggregation of a certain morphotype consists of cloned individuals.

Den Hartog (1997) mentioned the variability of morphology among Phyllodiscus specimens, but did not show images of the different morphotypes. Until now, field guides have provided the best information about the range of appearances. The difference among the morphotypes is due solely to the pseudotentacle morphology of each individual. Pseudotentacles are outpocketings of the column wall that can grow and extend in various directions, and can be smooth or uneven, straight and/or branched. During the day, the oral disc, mouth, and tentacles are retracted into the coelenteron, but the pseudotentacles remain extended

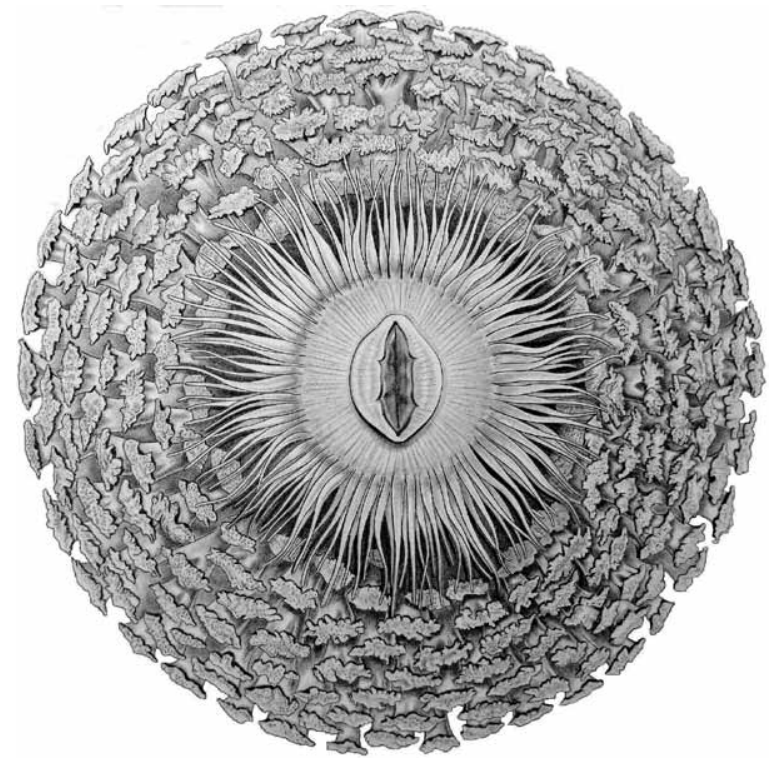

Fig. 2. Holotype of Phyllodiscus semoni. Schematic drawing showing column and extended tentacles (after Kwietniewski, 1898). The depicted animal most probably represented a morphotype resembling a relatively smooth disc.

and visible to other organisms. Because of this posture, Phyllodiscus individuals are not easily recognised as sea anemones, and they appear to be camouflaged and to fit in with their environment. This is achieved via crypsis (avoiding detection by blending in with background), masquerade (resemblance of inanimate or 
inedible objects), and/or mimicry (detected, but misidentified as its model organism) (Skelhorn et al., 2010a, b).

In the present paper we report for the first time on the co-occurrence of various Phyllodiscus morphotypes in the Spermonde Archipelago off Makassar (South Sulawesi, Indonesia), each of which appear to exhibit crypsis, mimicry, and/or masquerade by resembling branching and encrusting corals (mostly scleractinians and alcyonaceans) or dead rock covered by algae. Phyllodiscus individuals formed aggregations consisting of three different morphotypes: all three morphotypes co-occurring in a single assemblage on a reef slope, with all individuals within $25 \mathrm{~m}$ distance of one another. The simultaneous occurrence of multiple Phyllodiscus morphotypes in dense aggregations suggests that this is a highly polymorphic single species that uses asexual reproduction to reach high abundances. We provide field photographs to show the extraordinary amount of morphological variation found among individuals of Phyllodiscus, and the extent of their apparent camouflage. We also provide information to help distinguish the sea anemones from their model organisms, which will aid in the correct identification of these sea anemones by divers, field guides, and most importantly, scientists performing toxicology studies.

\section{Material and methods}

During mushroom coral surveys (in 1994-1998) in the shelf-based Spermonde Archipelago, off Makassar, South Sulawesi, Indonesia (Fig. 1), specimens ( $>150$ lots consisting of one or more individuals) of the highly polymorphic Phyllodiscus semoni (Anthozoa: Actiniaria: Aliciidae) were observed by use of the roving diver technique (see Hoeksema and Koh, 2009). The identifications were performed in the field and were based on the original species description and illustration by Kwietniewski $(1897,1898)$, which were brought to our attention by the late J.C. den Hartog, who also showed an interest in this particular species (Strack, 1993; Den Hartog, 1997). Specimens were photographed with a Sea \& Sea SX-1000 TTL Underwater camera with a strobe for extra illumination. Because the sea anemones resembled corals, examples of such look-alikes were also photographed. Unless stated otherwise, the first author is responsible for all fotographs and observations in the field.

The sea anemones were collected, fixed in a $10 \%$ formalin solution, and deposited in the coelenterate collection of the Netherlands Centre for Biodiversity, NCB Naturalis (= RMNH, formerly Rijksmuseum van Natuurlijke Historie) in Leiden. Morphology and cnidae of preserved material were further examined at NCB Naturalis in Leiden (the Netherlands) and The University of Kansas in Lawrence (USA). Specimens were dissected and examined under a dissecting microscope to determine fertility, number, and arrangement of mesenteries. Cnidae preparations were made from the vesicles, pseudotentacles, tentacles, mesenterial filaments, and column by smashing tissue with water under a coverslip; slides were viewed using a compound microscope and types of cnidae were noted.

\section{Results}

The possession of six pairs of complete mesenteries and nematocyst-laden vesicles of the column indicated that the specimens belonged to the family Aliciidae Duerden, 1895 (Carlgren, 1949). The outgrowths of the column, the pseudotentacles, occurred in a broad zone (rather than a single ring), which indicated that the specimens were in the genus Phyllodiscus. Phyllodiscus is a monotypic genus, and the specimens belong to the only species, P. semoni (Fig. 2). We are currently investigating whether this morphological variability relates to more than one species (Crowther and Hoeksema, in prep.).

Phyllodiscus semoni individuals were observed at nine reefs in the Spermonde Archipelago: Lumu Lumu, Pulau Badi, Kudingareng Keke, Bone Batang, Barrang Lompo, Bone Lola, Barrang Caddi, Samalona, and Bone Baku (Fig. 1). Most encounters with the sea anemone (either as individuals or as aggregations) occurred on mid-shelf reefs (approximately 20-40 m maximum depth), whilst on reefs close to the coastline, no specimens were found, and on the more offshore reefs, the species was rare. The sea anemones were attached to dead coral but could easily be detached, indicating that they were not sessile but sedentary. A few specimens were found detached, more or less drifting on or above the sandy bottom.

Solitary individuals of various morphotypes (including colour morphs) were observed, and most of them resembled dead coral rock covered by algae. Others looked like species of fleshy seaweeds with branched thalli, stony corals (Hexacorallia: Scleractinia) or soft corals (Octocorallia: Alcyonacea and Stolonifera), and therefore showing a large array of apparent mimicry (Figs 3-6). In these figures the sea anemones appear on 

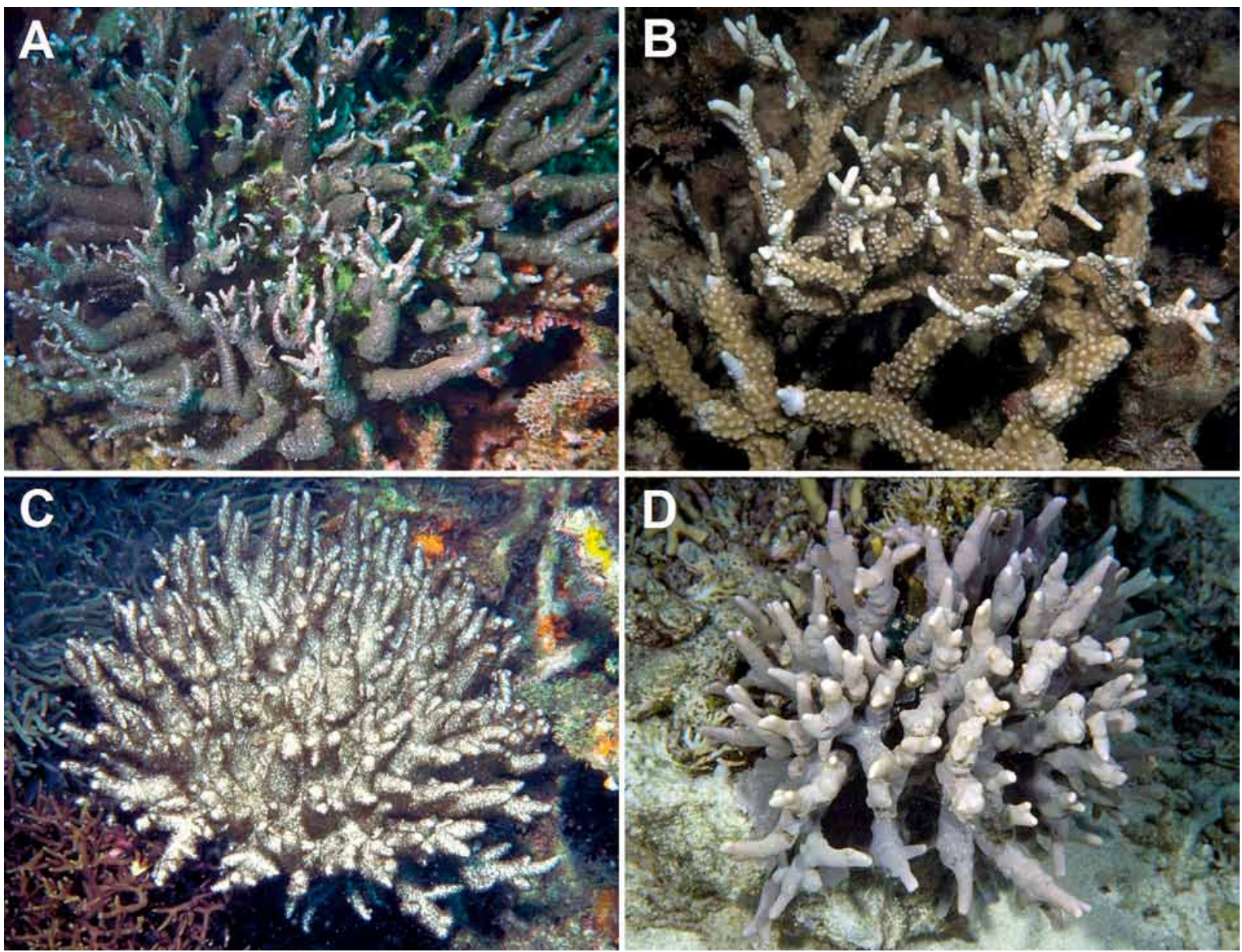

Fig. 3. Phyllodiscus semoni sea anemones (A, C) at South Sulawesi and examples of possible look-alike models (Scleractinia: B, D). A. Branching morph (Pulau Badi, 1997). B. Model for A: Anacropora sp. (eastern Sulawesi, 1999). C. Branching morph (Kudingareng Keke, 1997). D. Model for C: Porites cylindrica Dana, 1846 (Kudingareng Keke, 1994).

the left panel, and the presumed corresponding model organism on the right panel. Most Scleractinia lookalikes (compare Veron, 2000) mimicked branching corals belonging to the Acroporidae and Pocilloporidae (Figs 3-4). Among the Alcyonacea look-alikes (compare Fabricius and Alderslade, 2001; Van Ofwegen, 2008), Phyllodiscus morphotypes resembled encrusting and branching species of, for instance, the soft coral genera Asterospicularia Utinomi, 1951 (Asterospiculariidae), Klyxum Alderslade, 2000 and Sinularia May, 1898 (Alcyoniidae), and Efflatounaria Gohar, 1939, or other xeniids (Xeniidae) (compare Fabricius and Alderslade, 2001) (Figs 5-6). Furthermore, one observed specimen appeared to use stoloniferan octocorals as a model, such as Tubipora Linnaeus, 1758 , but it also appeared to resemble the gorgonian
Briareum violaceum (Quoy and Gaimard, 1833) (compare Fabricius and Alderslade, 2001) (Fig. 6E-G).

Aggregations of Phyllodiscus individuals were observed on and between dead Acropora branches (6-12 m depth) on the NW slope of the cay-crowned Kudingkareng Keke reef $\left(5^{\circ} 5.063^{\prime} \mathrm{S}, 119^{\circ} 10.168^{\prime} \mathrm{E}\right.$; June 1997). The largest aggregation consisted of three non-intermingling, adjacent groups of morphotypes (Fig. 7AB) within $25 \mathrm{~m}$ length of reef slope, each showing crypsis, mimicry, and/or masquerade (following terminology from Skelhorn et al., 2010a, b), either by resembling branching corals (branched shape, Fig. 7C) or dead coral rock covered by algae (shaggy disc, Fig. 7D; smooth disc, Fig. 7E). Each aggregation consisted of 10-25 individuals of various sizes. If these sea anemones had not occurred in aggregations they may have been less 

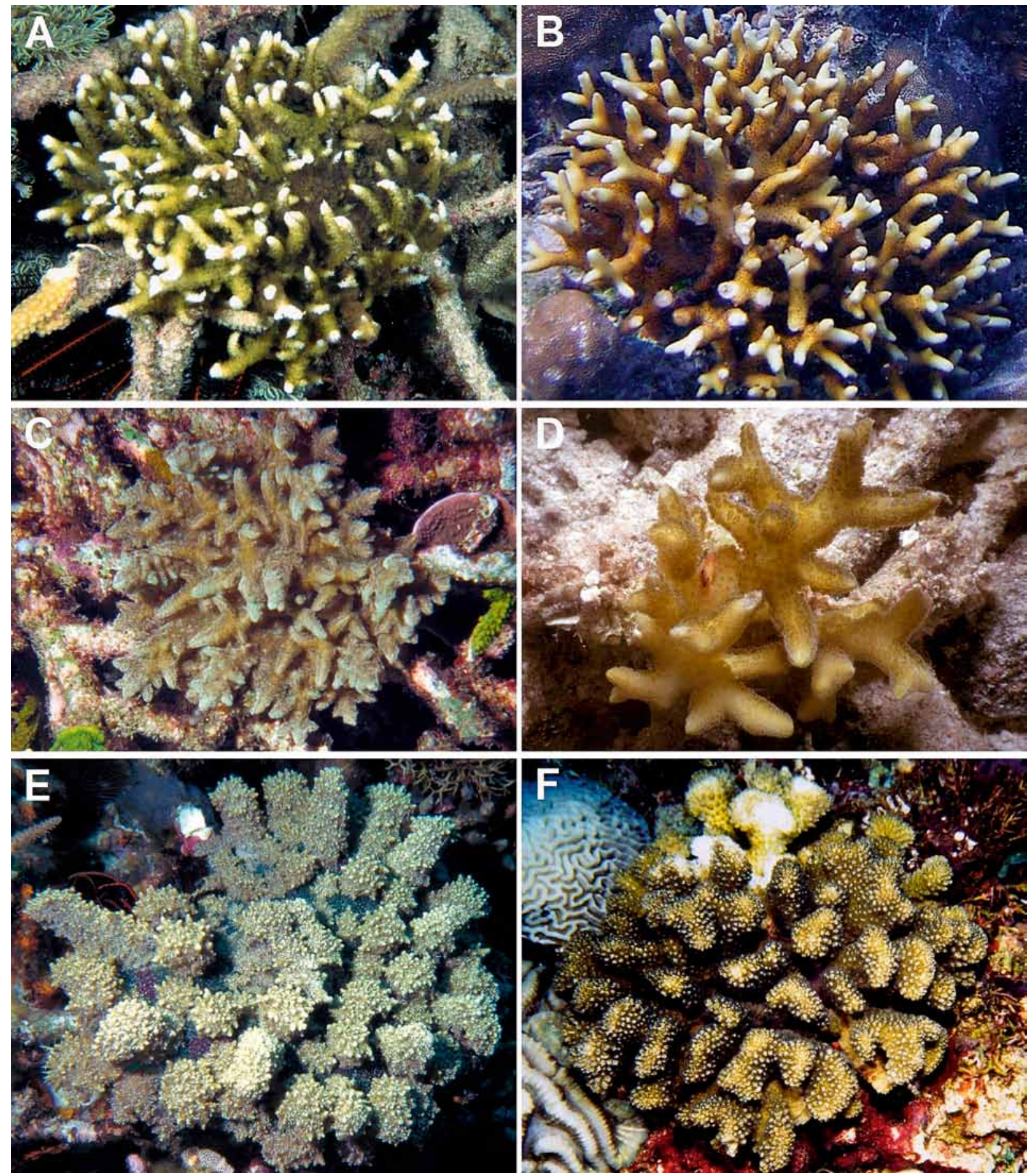

Fig. 4. Phyllodiscus semoni sea anemones (A, C, E) at South Sulawesi and examples of possible look-alike models (Scleractinia: B, D, F). A. Branching morph (Kudingareng Keke, 1997). B. Model for A: Seriatopora hystrix Dana, 1846 (East Kalimantan, 2003). C. Branching morph (Barang Lompo, 1996). D. Model for C: Seriatopora caliendrum Ehrenberg, 1834 (Lankai, 1997). E. Branching morph (Pulau Badi, 1996). F. Model for E: Pocillopora meandrina Dana, 1846 (Bali, 1998). 

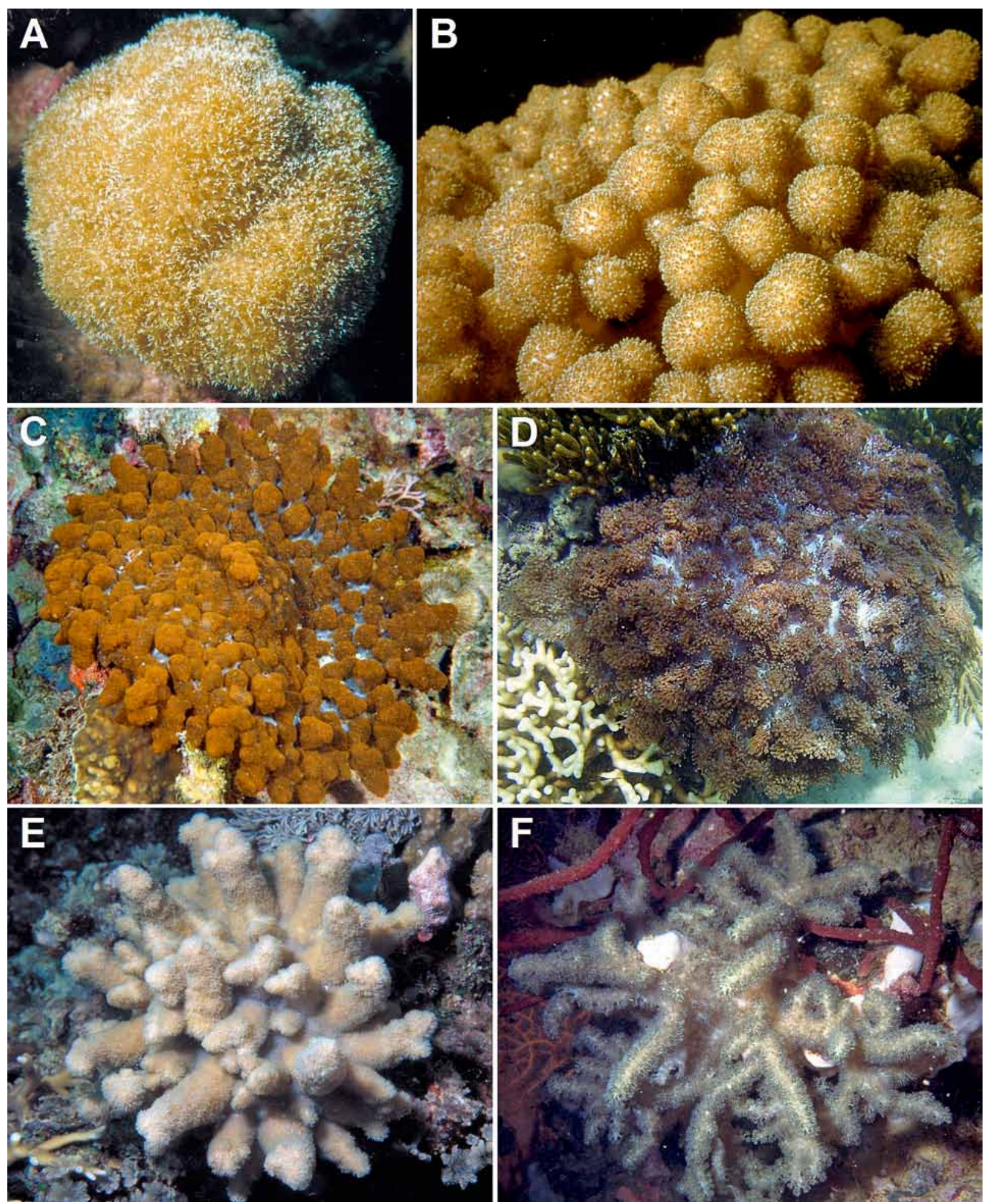

Fig. 5. Phyllodiscus semoni sea anemones (A, C, E) at South Sulawesi and examples of possible look-alike models (Alcyonacea: B, D, F). A Globular morph (Kudingareng Keke, 1997); see also Fig. 10. B. Model for A: Asterospicularia sp. (Bali, 2001, photo L.P. van Ofwegen). C. Discoid morph (Pulau Badi, 1994). D. Model for C: Efflatounaria sp. (East Kalimantan, 2003). E. Branching morph (Kudingareng Keke, 1998). F. Model for E: Klyxum sp. (Pulau Badi, 1996). 

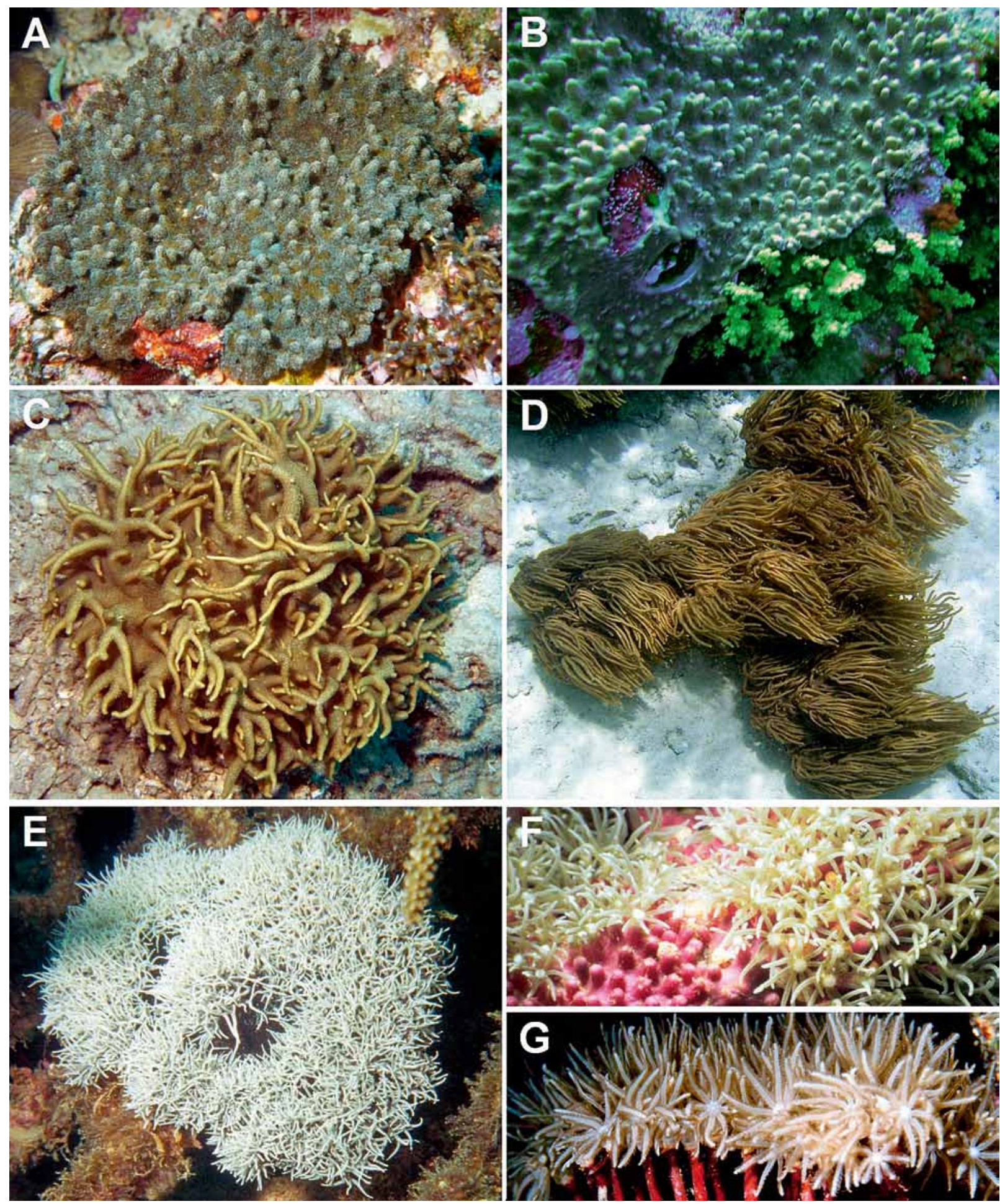

Fig. 6. Phyllodiscus semoni sea anemones (A, C, E) at South Sulawesi and examples of possible look-alike models (Alcyonacea and Stolonifera). A. Discoid morph (Kudingareng Keke, 1997). B. Model for A: Sinularia gravis Tixier-Durivault, 1970 (Palau, 2005, photo L.P. van Ofwegen). C. Branching morph (Bone Lola, 1997). D. Model for C: Sinularia flexibilis (Quoy and Gaimard, 1833) (East Kalimantan, 2003). E. Discoid morph (Barang Lompo, 1996). F. Model for E: Briareum sp. (Philippines, 1999, photo L.P. van Ofwegen). G. Model for E: Tubipora musica Linnaeus, 1758 (Bali, 2001). 

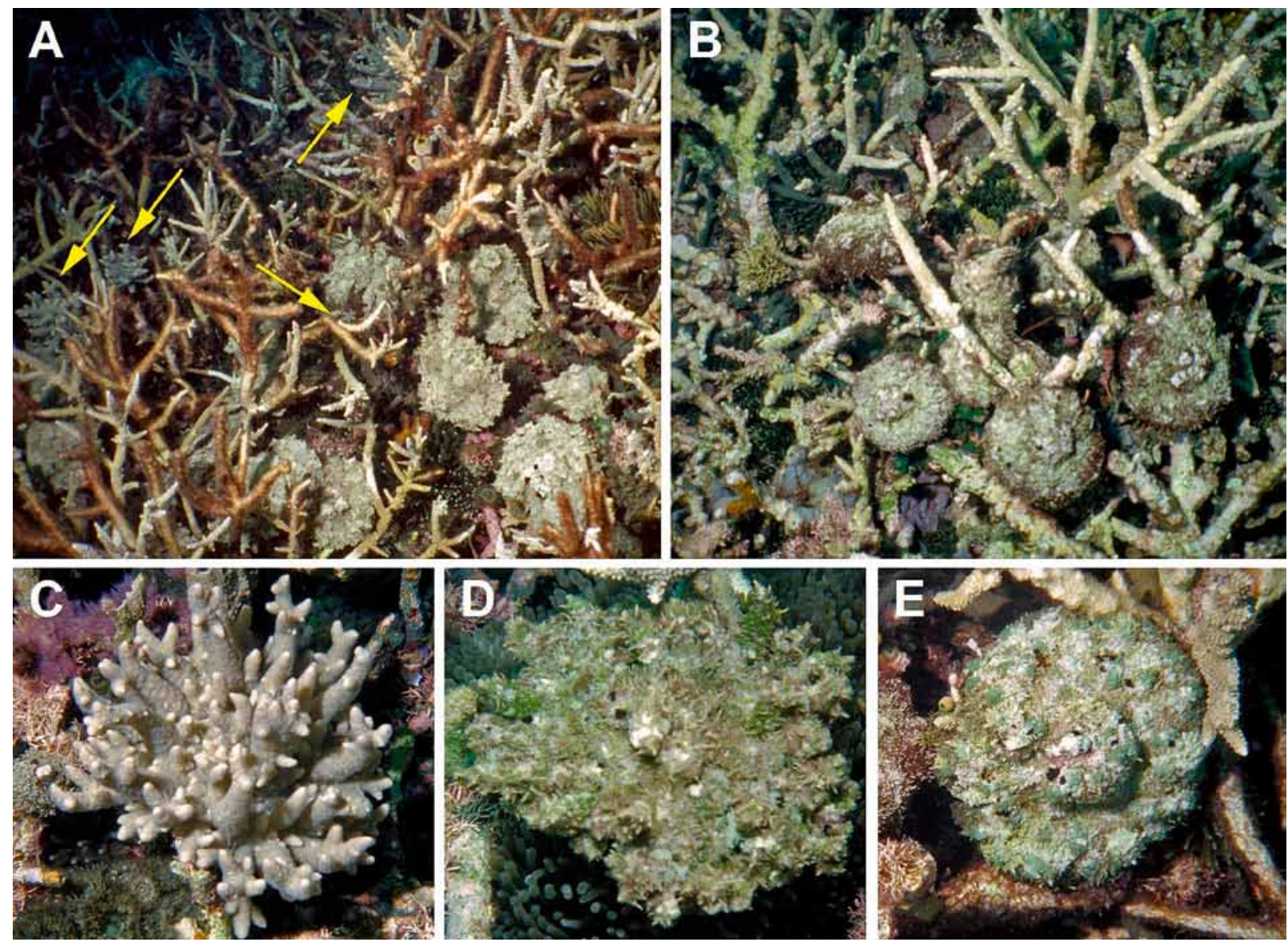

Fig. 7. Phyllodiscus semoni at South Sulawesi (Northwest side Kundingkareng Keke reef, Spermonde Archipelago, June 1997). Aggregations and individuals of three morphotypes: branched (A: arrows, C), shaggy disc (A, D), smooth disc (B, E). The latter resembles the schematic drawing of the holotype (Fig. 2).

obvious because of their camouflage. This is the first published account of a combined clustering of three distinct Phyllodiscus morphotypes. At a nearby location, a small aggregation of three well-camouflaged individuals of another morphotype was photographed (Fig. 8).

\section{Discussion}

\section{Cross-shelf distribution}

The habitat diversity of the Spermonde archipelago offers suitable conditions for Phyllodiscus to thrive, especially in the mid-shelf zone. The highest concentrations of individuals and the most morphotypes (including in aggregations) were encountered on mid-shelf reefs, and particularly on the wave-exposed northwest and west slopes of Kudingareng Keke reef, which is located outside the reach of the Jeneberang river plume (Hoeksema, 1990). This side of the reef is the most exposed to storm-generated waves (Hoeksema, 1988, 1990). Besides dense patches of living Acropora corals, areas of dead coral branches and unconsolidated rubble can be found here, which together form an ideal habitat for sea anemones that live attached to hard substrata, such as Phyllodiscus. As a whole, the Spermonde archipelago with its high concentration of patch reefs of wide-ranging distances offshore, and with slopes of varied exposures to wind energy and depth ranges, is rich in diverse species of reef-dwelling organisms such as reef corals, sea urchins, sea anemones, sponges, boring bivalves, gastropods, and large foraminifera (De Beer, 1990; Hoeksema, 1990; Renema et al., 2001; Kleemann and Hoeksema, 2002; Cleary et al., 2005; Becking et al., 2006; De Voogd et al., 2006; Cleary and De Voogd, 2007; Kokshoorn et al., 2007). 


\section{Polymorphism}

Intraspecific morphological variation is not uncommon in anthozoans such as corals and zoanthids (Hoeksema and Moka, 1989; Hoeksema, 1993, in press; Reimer et al., 2004, 2008; Gittenberger and Hoeksema, 2006; Todd, 2008; Stefani et al., 2011), but in actiniarians no other cases involving such a large range of morphotypes are known to us. Within sea anemone species, most of the documented intraspecific variation is due to colour; for example the temperate East Atlantic species Actinia equina (Linneaus, 1758) (Haylor et al., 1984; Solé-Cava and Thorpe, 1992; Watts et al., 2000) and the (sub)tropical West Atlantic Condylactis gigantea (Weinland, 1860) (Stoletzki and Schierwater, 2005), and the tropical species Cryptodendrum adhaesivum Klunzinger, 1877 and Heteractis magnifica (Quoy and Gaimard, 1833), both of which are known to host clownfishes (Dunn, 1981; Fautin and Allen, 1992). Even at the genus level, there is no other actiniarian (or even anthozoan) taxon that possesses this much morphological variation.

The extensive morphological variation seen in Phyllodiscus is due to the outgrowths of the column, the pseudotentacles. Phyllodiscus sea anemones, like many other shallow-water actiniarians, possess zooxanthellae. In some members of Aliciidae, including Phyllodiscus, the zooxanthellae are concentrated in special outgrowths of the column called pseudotentacles. The pseudotentacles provide increased surface area to house and display zooxanthellae to the sun, therefore providing maximum exposure to light for photosynthesis. During the day, the pseudotentacles are expanded, while at night the tentacles on the oral disc are expanded (Gladfelter, 1975; Fig. 9). Multiple pseudotentacles occur per Phyllodiscus, extending out from two-thirds of the column (the very top and bottom of the column are free from pseudotentacles). These outgrowths can be branched in various directions and to various degrees, thereby creating variation in pseudotentacle morphology, and therefore the different morphotypes.

For this publication, we assume that the differences in pseudotentacle morphology indicate intraspecific variation, although it has been hypothesised that they can also represent interspecific variation (Den Hartog, 1997). This question is difficult to answer, as there is apparently a continuum of morphotypes, from branched to flat or disc shapes. We are currently investigating whether this morphological diversity is intra- or interspecific, using pseudotentacle morphology and molecular sequence data, and in particular whether the pseudotentacle morphology can be used to delimit species boundaries in Phyllodiscus (Crowther and Hoeksema, in prep).

Den Hartog (1997) described three morphotypes of Phyllodiscus that he observed in Indonesia, and all descriptions relate to how the morphology of the sea anemone is similar to another organism at the locality; he describes 'variegated patches of algae-covered substratum', 'a bunch of algae', and 'a branched coral' (Den Hartog, 1997: 360). We suspect that the morphotypes of $P$. semoni are a result of the sea anemones employing the tactics of crypsis, mimicry, and/or masquerade via camouflage (Skelhorn et al., 2010a, b). Using camouflage to fit in with the surroundings, cryptic organisms avoid detection by predator or prey through blending in with their background. The three Phyllodiscus individuals in Fig. 8 are cryptic, as they are fitting in with the mottled algal-covered background to which they are attached. Organisms employing masquerade are also camouflaged, but resemble an inanimate or inedible object; it is assumed that the predator or prey detect the masquerading organism, but misidentify it as its model organism. The Phyllodiscus morphotypes that resemble algal-covered boulders or clumps of algae may be using masquerade to deter predation. Organisms that employ mimicry resemble a defended organism; it is assumed that the predator or prey detect the mimic but misidentify it as the defended model organism. The branched morphotypes of Phyllodiscus sea anemones resemble corals, which also possess nematocysts.

Without experimental trials, it is impossible to identify whether the morphotypes are employing any type of camouflage, including crypsis, mimicry, masquerade, or a combination of these. Experiments would need to demonstrate that appropriate organisms (i.e. potential predators or prey) perceive the sea anemones as cryptic or may mistake them for the items/organisms that they appear to resemble. So far, assumptions are based on the field observations by the authors.

\section{Aggregations}

Aggregations of large reef-dwelling sea anemones are not uncommon (Richardson et al., 1997; Brolund et al., 2004; Scott et al., 2011). Strack (1993: 49), in an account of the Rumphius Biohistorical Expedition to Ambon, mentioned that Den Hartog 'found an aggregation of ca. 80 individuals of the large and extremely painful stinging Phyllodiscus semoni'. He (Strack, 1993: Fig. 50) showed individuals of $P$. semoni clustered closely 

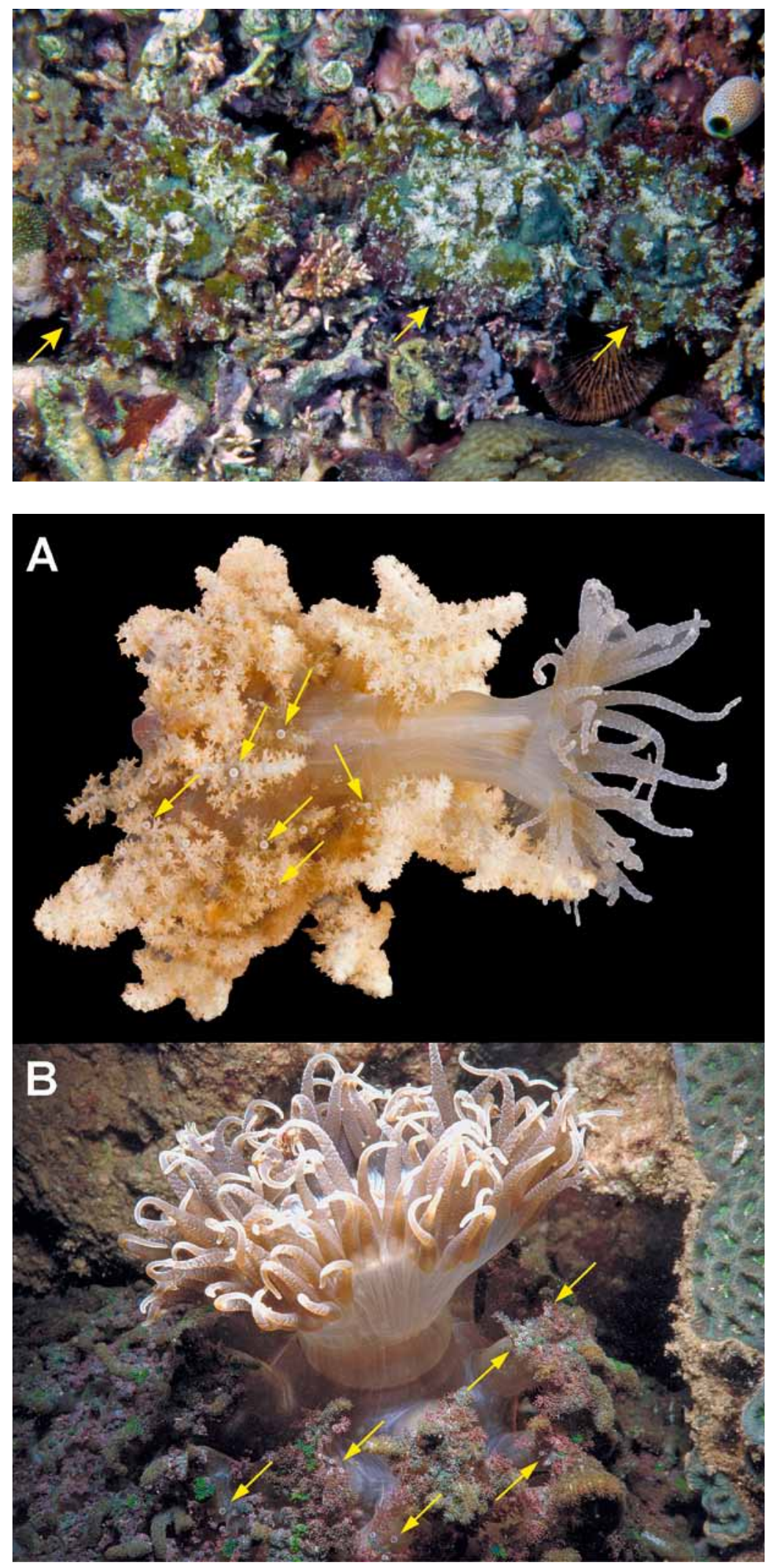

Fig. 8. Three Phyllodiscus individuals (arrows) camouflaged against their background (West side Kundingkareng Keke reef, Spermonde Archipelago, South Sulawesi, November 1997).
Fig. 9. Phyllodiscus semoni at South Sulawesi. Extended tentacles and pseudotentacles with vesicles (arrows) in a branched morphotype (A) and a smooth disc (B), West side Bone Baku reef, Spermonde Archipelago, May 1997. 
together in high abundance at a reef at the Islet of Pompo, east of Ambon. All individuals are of the same morphotype: the shape of the individual when tentacles are retracted is reminiscent of a head of cauliflower (also resembling specimens of the soft coral genus Asterospicularia) (Fig. 5AB). Phyllodiscus semoni is not mentioned again in Strack's (1993) report, so it is unknown whether other morphotypes were found in Ambon on that expedition.

We observed several individuals of this morphotype and others at Ambon (in 1996), including small specimens clustered next to a larger individual (Fig. 10). From this observation, we infer that Phyllodiscus relies on asexual reproduction (perhaps pedal laceration, but the mode of asexual reproduction is unknown) to reach high densities of individuals in a given area. Similarly, free-living mushroom corals (Scleractinia: Fungiidae) can form dense monospecific populations as a result of asexual reproduction by either budding or fragmentation (Hoeksema, 2004; Hoeksema and Gittenberger, 2010; Hoeksema and Waheed, 2011). Such monospecific aggregations are very striking because dense mushroom coral assemblages usually consist of mixed species (e.g. Hoeksema, 1991; Goffredo and ChadwickFurman, 2000; Elahi, 2008; Hoeksema and Koh, 2009; Hoeksema and Matthews, 2011). In populations of other anthozoan species that rely on asexual reproduction, the relative frequencies of different morphotypes appear to depend heavily on the replication rate of clonal genotypes (Ayre and Willis, 1988; McFadden, 1997; Whitaker, 2006). That Phyllodiscus aggregations generally consisted of individuals ranging in size but not in morphology suggests that these sea anemones were clones. If the aggregations were a result of sexual reproduction, we would not expect each aggregation to consist of identical morphotypes but to be a mixed assemblage of morphotypes or of closely related species. Moreover, if the Phyllodiscus individuals would be of different genotypes, they might attack each other, causing adjacent individuals to move away from one another as in the sedentary temperate sea anemone $A c$ tinia equina, leading to well-spaced distributions instead of aggregations (Briffa and Greenaway, 2011).

Asexual reproduction or cloning may play an important role in the life history of anthozoans and other cnidarians as a mechanism to occupy substrate surface, while some also use mobility to spread outward and to remain literally on top of competitors (Francis, 1988; Karlson, 1988; Fautin, 1991; Hoeksema, 2004; Geller et al., 2005; Hoeksema and Gittenberger, 2010). Some competitive anthozoans show aggressive behavior and are known to reach high concentrations and dense substrate cover at the expense of other benthic animals by use of their venom or by simply overgrowing them (Chadwick, 1987; England, 1987; Chadwick and Adams, 1991; Chadwick-Furman and Spiegel, 2000; Chen et al., 2008). Due to the high toxicity of their venoms, some anthozoans, especially sea anemones, are also know to be potentially harmful to man by inflicting long-lasting wounds (Hansen and Halstead, 1971; Halstead, 1988; Williamson et al., 1996; Mizuno et al., 2000; Nagata et al., 2006; Bergbauer et al., 2007).

\section{Co-occurrence of morphotypes in aggregations}

We provide the first observations (Fig. 7) of three different morphotypes co-occurring within aggregations on the same reef. As discussed in the previous section, we suspect that the individuals of identical morphotypes within one aggregation are clonal. Once the pseudotentacles have been developed, it is unlikely they are plastic and can change their growth and therefore appearance and morphotype. For example, we consider it highly unlikely that individuals with branching pseudotentacle morphology (Fig. 7C) could change their morphology to become more disc-shaped like the other morphotypes at this locality (Fig. 7D, E). Regarding Phyllodiscus morphotypes, which all occur in more or less the same environment, there appears to be no indication of ecophenotypic plasticity as shown by many scleractinian corals (e.g. Todd, 2008; Stefani et al., 2011). Accordingly, we presume that each morphotype aggregation in Fig. 7 is a separate clonal group. The co-occurrence of three morphotypes at the same locality, and therefore under the same environmental influences, indicates that the morphology is not due to ecophenotypic variation, but that it is under genetic control.

\section{Misidentification of venomous sea anemones}

Correct identification is important for specimens of $P$. semoni, because they are used in many toxicological studies. The toxin of $P$. semoni is known to be very dangerous to humans; it may cause skin lesions, ulcers, and necrosis (Williamson et al., 1996: Plates 8.168.18), and at least one fatal sting is known from the central Philippines (Erhardt and Knop, 2005).

Particularly in Japan, where specimens were found at Okinawa, P. semoni has been subjected to various toxicological analyses (Mizuno et al., 2000, 2007; Nagai et al., 2002a, b; Nagata et al., 2006; Satoh et al., 


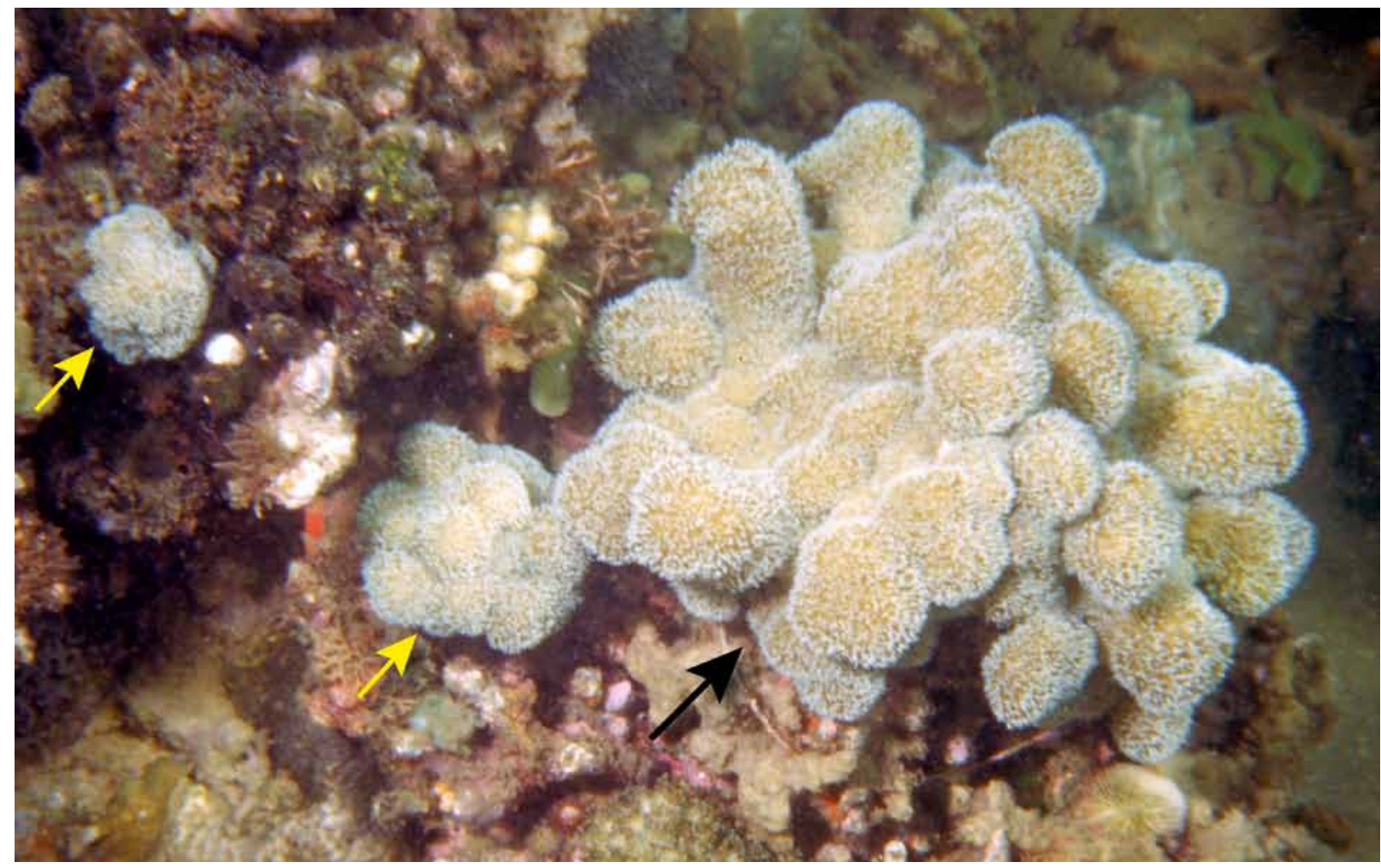

Fig. 10. Two small (yellow arrows) and one large (black arrow) Phyllodiscus individuals of the same morphotype at Ambon (northern coastline of Ambon Bay, near Tawari, November 1996).

2007). Its toxin not only causes damage to skin that has been in contact with the sea anemone (of which the first author knows too well), but also affects the human kidney (Nagai et al., 2002a, b; Mizuno et al., 2007; Satoh et al., 2007). Illustrations of the Okinawan specimens (Oshiro et al., 2001; Uchida, 2001) resemble the smooth disc morphotype (Fig. 7E) and have been locally called 'Unbachi-isoginchaku' (Nagai et al., 2002a, b; Mizuno et al., 2007), which means Wasp Sea Anemone in Japanese. There are also reports of another venomous sea anemone from Okinawa, which is referred to as 'Fusa-unbachi-isoginchaku' (Uechi et al., 2005a, b), meaning Tassel-shaped Wasp Sea Anemone, owing to its branched appearance resembling a scleractinian coral (Oshiro et al., 2004; Uechi et al., 2005a, b). Based on figures in Oshiro et al. (2001) and Uchida (2001), these individuals are a branched morphotype of Phyllodiscus, resembling a soft coral (Fig. 6E, 7C), but have been erroneously identified as Actineria villosa Quoy and Gaimard in De Blainville, 1830 (for nomenclature, see Fautin et al., 2007). The identification of specimens reported as
A. villos $a$ and used in other toxicological studies (Oshiro et al., 2001, 2004; Uechi et al., 2005a, b), should be treated with caution, because of the confusion between A. villosa and P. semoni.

Hansen and Halstead (1971) reported on a sea anemone found at Cam-Ranh Bay, southern Vietnam, that stung US military personnel who swam in the bay. They identified it as the actinodendrid Actinodendron plumosum Haddon, 1898, another species known for its painful sting. However, we agree with Den Hartog's (1997) statement that the sea anemones of Hansen and Halstead (1971) were erroneously identified, and were actually individuals of $P$. semoni. We base this on multiple lines of evidence. Figure $4 \mathrm{~b}$ of Hansen and Halstead (1971: 128) shows a nematocyst type that is found in vesicles of Aliciidae sea anemones, the family to which $P$. semoni belongs, and this nematocyst type is never found in Actinodendridae, the family to which A. plumosum belongs. Photographs in Hansen and Halstead (1971) show two morphotypes that they called the 'flowery- type' and 'top hat', which correlate strongly with the morphotypes of $P$. semoni shown in 
Fig. 7B, E. Additionally, Hansen and Halstead (1971) mentioned that the sea anemones lived attached to rock (like $P$. semoni) rather than buried in sand (like A. plumosum). Based on these re-evaluations, we are certain Hansen and Halstead (1971) were not dealing with Actinodendron plumosum, but with P. semoni.

It is important to understand and appreciate that Phyllodiscus sea anemones have a wide range of morphotypes, some of which have been confused with other actiniarian species. The co-occurrence of multiple morphotypes at high densities is an important observation towards a better understanding and recognition of these hazardous sea anemones, especially because their high densities increase the risk of injuries to man.

\section{Distinguishing mimics from models}

Phyllodiscus sea anemones can be distinguished from their look-alike counterparts in various ways. Sea anemones are strictly soft-bodied and never produce a hard skeleton like a scleractinian coral. Also, sea anemones are always solitary individuals and never form colonies (with a possible exception, see Häussermann and Försterra, 2003); however, the single oral disc and mouth are retracted and are not usually noticed during the day. Superficially, the sea anemones differ from corals and other models by showing more radial symmetry in their body plan (Figs 3-8) and having a body surface that is fluffier. By being softer, their body moves more in turbulent water. After aggravation, specimens extend the column and oral disc with mouth and tentacles, while globular vesicles remain visible on the pseudotentacles of the main body around the column (Fig. 9). These vesicles are small bubble-like bumps of which the ectoderm is dense with nematocysts. Compared to sea anemones of Actinodendridae (which they have been confused with), Phyllodiscus individuals are sedentary by having a distinct pedal disc that attaches to a hard substrate, while actinodendrids burrow into soft sediment. Finally, Phyllodiscus sea anemones are common hosts to commensal shrimp species of the pontoniid genera Ancylomenes Okuno and Bruce, 2010 and Periclimenes Costa, 1844, like A. sarasvati (Okuno, 2002), A. venustus (Bruce, 1989), and P. brevicarpalis (Schenkel, 1902) (Fig. 11A; Fransen, 1997; Humann and DeLoach, 2010: 121), which dwell in pairs or in swarms over their upper surfaces. Unlike their model counterparts, the sea anemones are also occasionally parasitised by host- specific wentletrap snails of the genus Epitonium Röding, 1798 (Fig. 11BC; Kokshoorn et al., 2007).

The kind of mimicry involved is most likely Müllerian mimicry because the mimics and their models both may have to defend themselves against potential predators, while in the case of Batesian mimicry, the mimic (Phyllodiscus) would be considered harmless and the imitated model dangerous (Ruxton et al., 2004). The possibility that corals and other model animals would mimic the sea anemones rather than the other way is very unlikely. This would imply that this kind of evolution would have re-occurred many times in various groups of anthozoans, such as scleractinians and octocorals (Figs 3-6). Moreover, not only the resembling counterpart species would have evolved to resemble a sea anemone model but also many of their relatives that look like the model, which in that case should also resemble the sea anemone. Hence, closely related model species, such as some pocilloporids, are exceptional (Fig. 4). Furthermore, the coral models are generally more common and widespread than Phyllodiscus and would not have an advantage by mimicking rare counterparts. It would also not be clear why some particular coral species would need to employ mimicry and many others not.

\section{Application of multiple defense strategies}

Phyllodiscus employs various camouflage strategies to hide itself, by the application of crypsis, mimicry, or masquerade. Despite being zooxanthellate, the animals need to eat, thus being inconspicuous may increase chances of prey coming into contact with the sea anemone. However, it is more likely that Phyllodiscus uses adaptive colouration to avoid predation. Sea turtles, for instance, are known to feed on sea anemones and other stinging cnidarians despite their venomous nematocysts (Den Hartog, 1979; Den Hartog and Van Nierop, 1984; Van Nierop and Den Hartog, 1984; Ates, 1991; Plotkin et al., 1993; Tomas et al., 2001; Arai, 2005). Some fishes, for example reefdwelling butterfly fishes (Chaetodontidae), also eat sea anemones (Ottaway, 1977; Ates, 1989; Yoshiyama et al., 1996; Augustine and Muller-Parker, 1998; Porat and Chadwick-Furman, 2004). While the camouflage/adaptive colouration helps to avoid detection by predators, the extreme morphological variation may assist even further by preventing the development of search images by predators that otherwise are able to recognise prey despite the camouflage. In other words, it is more difficult for predators to know what 

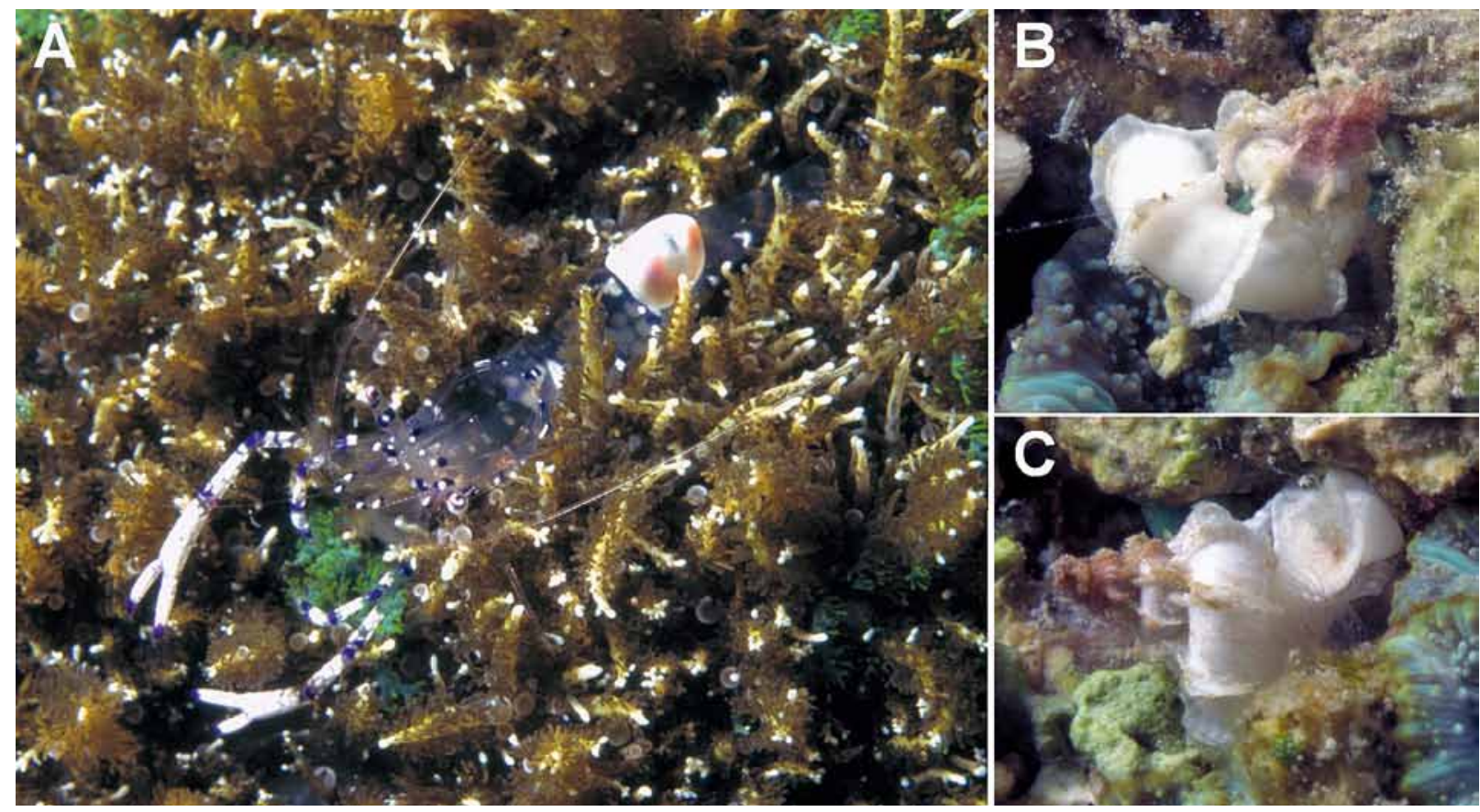

Fig. 11. Associated invertebrates with Phyllodiscus semoni at South Sulawesi (Spermonde Archipelago, Kudingareng Keke, 1997). A. A shrimp Ancylomenes venustus (Pontoniinae), on the upper surface of a sea anemone. B, C. A gastropod, Epitonium sp. (Epitoniidae), from the base of a sea anemone.

Phyllodiscus individuals may look like when they are trying to detect and locate it as a possible prey (Lawrence and Allen, 1983; Reid and Shettleworth, 1992). The pseudotentacles of Phyllodiscus may provide camouflage and therefore protection during the day by evading recognition as an actiniarian.

Occurrence in aggregations may not be a benefit because masquerading species are most successful in avoiding predation when they are rare in comparison to their models (Skelhorn et al., 2011): the repetition shown by the same shape facilitates recognition (see e.g. Figs 7-8). Therefore it remains a question why such aggregations occur. Either, after reproduction most aggregated Phyllodiscus individuals did not have a chance to disperse (for instance by a lack of currents) or sea anemones that did not disperse far from parent individuals had a higher rate of survival than those that distributed further away to a less suitable habitat. This could be because the morphotype, for camouflage purposes, is most effective in the current background. The occurrence of polymorphism (or polyphenism) as shown by Phyllodiscus in the present study, and the polymorphic American peppered moth caterpillar that mimics different tree twigs (Skelhorn and Ruxton, 2010), may compensate for the large number of individuals present. Hence, polymorphism together with camouflage may function as synergetic antipredatory traits.

In this study, we present new information on Phyllodiscus to aid in recognition of this highly polymorphic and presumably camouflaged sea anemone. Further studies are underway to evaluate whether the large amount of morphological variation is intra- or interspecific.

\section{Acknowledgements}

The research permit to BWH was issued by the Indonesian Institute of Sciences (LIPI), Jakarta. The fieldwork was supported through WOTRO grant W77-96. Local support was given by Dr. Alfian Noor, Universitas Hasanuddin. ALC received a Martin Fellowship for her research at NCB Naturalis. Dr. Leendert P. van Ofwegen supplied photographs of octocorals and assisted in their identification. Dr. Charles H.J.M. Fransen identified the commensal shrimps. Ms. Sancia E.T. van der Meij assisted in the layout of the illustrations. Dr. James D. Reimer kindly provided us with literature from Japan. Drs Daphne Fautin, Paulyn Cartwright, and Luciana Gusmão are thanked for providing invaluable discussions and critical comments pertaining to the manuscript. Other constructive remarks were given by Dr. Estefanía Rodríguez, Dr. 
John Skelhorn, and one anonymous reviewer. This paper is dedicated to the memory of the naturalist and sea anemone specialist J.C. (Koos) den Hartog (1942-2000), who was a dedicated friend and member of the Naturalis marine research team.

\section{References}

Alderslade P. 2000. Four new genera of soft corals (Coelenterata: Octocorallia), with notes on the classification of some established taxa. Zoologische Mededelingen, Leiden 74: 237-249.

Arai MN. 2005. Predation on pelagic coelenterates: a review. Journal of the Marine Biological Association of the United Kingdom 85: 523-536.

Ates RML. 1989. Fishes that eat sea anemones, a review. Journal of Natural History 23: 71-79.

Ates RML. 1991. Predation on Cnidaria by vertebrates other than fishes. Hydrobiologia 216/217: 305-307.

Augustine L, Muller-Parker G. 1998. Selective predation by the mosshead sculpin Clinocottus globiceps on the sea anemone Anthopleura elegantissima and its two algal symbionts. Limnology and Oceanography 43: 711-715.

Ayre DJ, Willis BL. 1988. Population structure in the coral Pavona cactus: clonal genotypes show little phenotypic plasticity. Marine Biology 99: 495-505.

Becking LE, Cleary DFR, de Voogd NJ, Renema W, de Beer M, van Soest RWM, Hoeksema BW. 2006. Beta-diversity of tropical marine assemblages in the Spermonde Archipelago, Indonesia. Marine Ecology 27: 76-88.

Bergbauer M, Myers RF, Kirschner M. 2007. Dangerous marine animals: Mediterranean, Caribbean, Indo-Pacific. London: A \& C Black.

Briffa M, Greenaway J. 2011. High in situ repeatability of behaviour indicates animal personality in the beadlet anemone Actinia equina (Cnidaria). PLoS ONE 6: e21963.

Brolund TM, Tychsen A, Nielsen LE, Arvedlund M. 2004. An assemblage of the host anemone Heteractis magnifica in the northern Red Sea, and distribution of the resident anemonefish. Journal of the Marine Biological Association of the United Kingdom 84: 671-674.

Bruce AJ. 1989. A report on some coral reef shrimps from the Philippine Islands. Asian Marine Biology 6: 173-192.

Carlgren O. 1949. A survey of the Ptychodactiaria, Corallimorpharia and Actiniaria. Kungliga Svenska Vetenskapsakademiens Handlingar (3)1(1): 1-121.

Chadwick NE. 1987. Interspecific aggressive behavior of the corallimorpharian Corynactis californica (Cnidaria: Anthozoa): effects on sympatric corals and sea anemones. Biological Bulletin 173: 110-125.

Chadwick NE, Adams C. 1991. Locomotion, asexual reproduction, and killing of corals by the corallimorpharian Corynactis californica. Hydrobiologia 216/217: 263-269.

Chadwick-Furman NE, Spiegel M. 2000. Abundance and asexual reproduction of the tropical corallimorpharian Rhodactis rhodostoma. Invertebrate Biology 119: 351-360.

Chen TS, Ho CT, Jan RQ. 2008. A sea anemone outbreak eliminates damselfish territories from fringing reefs in southern Taiwan. Zoological Studies 47: 317.
Cleary DFR, Becking LE, de Voogd NJ, Renema W, de Beer M, van Soest RWM, Hoeksema BW. 2005. Variation in the diversity and composition of benthic taxa as a function of distance offshore, depth and exposure in the Spermonde Archipelago, Indonesia. Estuarine Coastal and Shelf Science 65: 557-570.

Cleary DFR, de Voogd NJ. 2007. Environmental determination of sponge assemblages in the Spermonde Archipelago, Indonesia. Journal of the Marine Biological Association of the United Kingdom 87: 1669-1676.

Coleman N. 2000. Marine life of the Maldives. Apollo Bay: Atoll Editions.

Costa OG. 1844. Su due nuovi generi di Crostacei decapodi macrouri nota. Annali della Accademia degli Aspiranti Naturalisti, Napoli 2: 285-290.

Dana JD. 1846-1849. United States Exploring Expedition during the years 1838-1842. Zoophytes 7: 1-740. Philadelphia: Lea \& Blanchard.

De Beer M. 1990. Distribution patterns of regular sea urchins (Echinodermata: Echinoidea) across the Spermonde Shelf, SW Sulawesi (Indonesia). Pp. 165-169 in: De Ridder C, Dubois P, Lahaye MC, Jangoux M, eds, Echinoderm Research. Rotterdam: Balkema.

De Blainville HMD. 1830. Dictionnaire des Sciences Naturelles. Strasbourg, Paris: FG Levrault.

Den Hartog JC. 1979. Notes on the food of sea turtles: Eretmochelys imbricata (Linnaeus) and Dermochelys coriacea (Linnaeus). Netherlands Journal of Zoology 30: 595-611.

Den Hartog JC. 1997. The sea anemone fauna of Indonesian coral reefs. Pp. 351-370 in: Tomascik T, Mah AJ, Nontji A, Moosa MK, eds, The ecology of the Indonesian seas 1 . Singapore: Periplus Editions.

Den Hartog JC, van Nierop MM. 1984. A study on the gut contents of six leathery turtles Dermochelys coriacea (Linnaeus) (Reptilia: Testudines: Dermochelyidae) from British waters and from the Netherlands. Zoologische Verhandelingen, Leiden 209: 1-36.

De Voogd NJ, Cleary DFR, Hoeksema BW, Noor A, Van Soest RWM. 2006. Sponge betadiversity in the Spermonde Archipelago, Indonesia. Marine Ecology Progress Series 309: 131-142.

Duerden JE. 1895. On the genus Alicia (Cladactis), with an anatomical description of A. costae, Panc. Annals and Magazine of Natural History 15: 213-218.

Dunn DF. 1981. The clownfish sea anemones: Stichodactylidae (Coelenterata: Actiniaria) and other sea anemones symbiotic with pomacentrid fishes. Transactions of the American Philosophical Society 71: 1-115.

Ehrenberg CG. 1834. Beitrage zur physiologischen Kenntniss der Corallenthiere im Allgemeinen und besunders des Rothen Meeres. Abhandlungen Kaiserliche Akademie der Wissenschaften Berlin 1832: 250-380.

Elahi R. 2008. Effects of aggregation and species identity on the growth and behavior of mushroom corals. Coral Reefs 27: 881-885.

England KW. 1987. Certain Actiniaria from the Red Sea and tropical Indo-Pacific. Bulletin of the British Museum (Natural History) Zoology Series 53: 205-292.

Erhardt H, Knop D. 2005. Corals. Indo-Pacific field guide. Frankfurt: IKAN Unterwasserarchiv. 
Fabricius K, Alderslade P. 2001. Soft corals and sea fans; a comprehensive guide to the tropical shallow water genera of the central-west Pacific, the Indian Ocean and the Red Sea. Townsville: Australian Institute of Marine Science.

Fautin DG. 1991. Developmental pathways of anthozoans. Hydrobiologia 216/217: 143-149.

Fautin DG, Allen GR. 1992. Field guide to anemonefishes and their host sea anemones. Perth: Western Australian Museum.

Fautin DG, Zelenchuk T, Raveendran D. 2007. Genera of orders Actiniaria and Corallimorpharia (Cnidaria, Anthozoa, Hexacorallia), and their type species. Zootaxa 1668: 183-244.

Fosså SV, Nilsen AJ. 1998. The modern coral reef aquarium. Volume 2. Bornheim: Birgit Schmettkamp Verlag.

Francis L. 1988. Cloning and aggression among sea anemones (Coelenterata: Actiniaria) of the rocky shore. Biological Bulletin 174: 241-253.

Fransen CHJM. 1997. Indonesian pontoniine shrimps. Pp. 10641075 in: Tomascik T, Mah AJ, Nontji A, Moosa MK, eds, The ecology of the Indonesian seas 2. Singapore: Periplus Editions.

Geller JB, Fitzgerald LJ, King CE. 2005. Fission in Sea Anemones: Integrative Studies of Life Cycle Evolution. Integrative and Comparative Biology 45: 615-622.

Gittenberger A, Hoeksema BW. 2006. Phenotypic plasticity revealed by molecular studies on reef corals of Fungia (Cycloseris) spp. (Scleractinia: Fungiidae) near river outlets. Contributions to Zoology 75: 195-201.

Gladfelter WB. 1975. Sea anemone with zooxanthellae: simultaneous contraction and expansion in response to changing light intensity. Science 189: 570-571.

Goffredo S, Chadwick-Furman NE. 2000. Abundance and distribution of mushroom corals (Scleractinia: Fungiidae) on a coral reef at Eilat, northern Red Sea. Bulletin of Marine Science 66: 241-254.

Gohar HAF. 1939. On a new xeniid genus Efflatounaria. Annual Magazine of Natural History (11) 3: 32-36.

Gosliner TM, Behrens DW, Williams GC. 1996. Coral reef animals of the Indo-Pacific. Monterey: Sea Challengers.

Haddon AC. 1898. The Actiniaria of Torres Straits. Scientific Transactions of the Royal Dublin Society 6: 393-520.

Halstead B. 2000. Coral Sea reef guide. Danville: Sea Challengers.

Halstead BW. 1988. Poisonous and venomous marine animals of the world. Princeton: Darwin Press.

Hansen PA, Halstead BW. 1971. The venomous sea anemone Actinodendron plumosum Haddon of South Vietnam. Micronesica 7: 123-136.

Häussermann V, Försterra G. 2003. First evidence for coloniality in sea anemones. Marine Ecology Progress Series 257: 291-294.

Haylor S, Thorpe JP, Carter MA. 1984. Genetic and ecological differentiation between sympatric colour morphs of the common intertidal sea anemone Actinia equina. Marine Ecology Progress Series 16: 281-289.

Hoeksema BW. 1988. Mobility of free-living fungiid corals (Scleractinia), a dispersion mechanism and survival strategy in dynamic reef habitats. Proceedings 6th International Coral Reef Symposium Townsville, Australia 2: 715-720.
Hoeksema BW. 1990. Systematics and ecology of mushroom corals (Scleractinia: Fungiidae). PhD Thesis, Leiden University.

Hoeksema BW. 1991. Control of bleaching in mushroom coral populations (Scleractinia: Fungiidae) in the Java Sea: stress tolerance and interference by life history strategy. Marine Ecology Progress Series 74: 225-237.

Hoeksema BW. 1993. Phenotypic corallum variability in recent mobile reef corals. Courier Forschungsinstitut Senckenberg 164: 263-272.

Hoeksema BW. 2004. Impact of budding on free-living corals at East Kalimantan, Indonesia. Coral Reefs 23: 492.

Hoeksema BW. Extreme morphological plasticity enables a free mode of life in Favia gravida (Ascension Island, Atlantic Ocean). Marine Biodiversity (in press).

Hoeksema BW, Gittenberger E. 2010. High densities of mushroom coral fragments at West Halmahera, Indonesia. Coral Reefs 29: 691.

Hoeksema BW, Koh EGL. 2009. Depauperation of the mushroom coral fauna (Fungiidae) of Singapore (1860s-2006) in changing reef conditions. Raffles Bulletin of Zoology Supplement 22: 91-101.

Hoeksema BW, Matthews JL. 2011. Contrasting bleaching patterns in mushroom coral assemblages at Koh Tao, Gulf of Thailand. Coral Reefs 30: 95.

Hoeksema BW, Moka W. 1989. Species assemblages and ecomorph variation of mushroom corals (Scleractinia: Fungiidae) related to reef habitats in the Flores Sea. Netherlands Journal of Sea Research 23: 149-160.

Hoeksema BW, Waheed Z. 2011. Initial phase of autotomy in fragmenting Cycloseris corals at Semporna, eastern Sabah, Malaysia. Coral Reefs, doi: 10.1007/s00338-011-0807-6.

Humann P, DeLoach N. 2010. Reef creature identification. Tropical Pacific. Jacksonville: New World Publications.

Karlson RH. 1988. Growth and survivorship of clonal fragments in Zoanthus solanderi Lesueur. Journal of Experimental Marine Biology and Ecology 123: 31-39.

Kleemann K, Hoeksema BW. 2002. Lithophaga (Bivalvia: Mytilidae), including a new species, boring in mushroom corals (Scleractinia: Fungiidae) at South Sulawesi, Indonesia. Basteria 66: 11-24.

Klunzinger CB. 1877. Die Korallthiere des Rothen Meeres. 1: Die Alcyonarien und Malacodermen. Berlin: Gutmann'schen Buchhandlung.

Kokshoorn B, Goud J, Gittenberger E, Gittenberger A. 2007. Epitoniid parasites (Gastropoda, Caenogastropoda, Epitoniidae) and their host sea anemones (Cnidaria, Actiniaria, Ceriantharia) in the Spermonde archipelago, Sulawesi, Indonesia. Basteria 71: 33-56.

Kwietniewski CR. 1897. Ein Beitrag zur Anatomie und Systematik der Actiniarien. PhD Thesis, Universität Jena.

Kwietniewski CR. 1898. Actiniaria von Ambon und Thursday Island. Zoologische Forschungsreisen in Australien und dem Malayischen Archipel von Richard Semon. 5: Systematik, Tiergeographie, Anatomie wirbelloser Tiere. Jena: Gustav Fischer.

Lawrence ES, Allen JA. 1983. On the term "search image". Oikos 40: 313-314.

Linneaus C. 1758. Systema Naturae. Regnum Animale. Laurentii Salvii, Holmiae, Stockholm. 
May W. 1898. Die von Dr. Stuhlmann im Jahre 1889 gesammelten ostafrikanischen Alcyonaceen des Hamburger Museums. Jahrbuch Hamburgischen Wissenschaftlichen Anstalten 15 (Beiheft 2): 138.

McFadden CS. 1997. Contributions of sexual and asexual reproduction to population structure in the clonal soft coral, $A l$ cyonium rudyi. Evolution 51: 112-126.

Mizuno M, Nishikawa K, Yuzawa Y, Kanie T, Mori H, Araki Y, Hotta N, Matsuo S. 2000. Acute renal failure after a sea anemone sting. American Journal of Kidney Diseases 36: E10.

Mizuno M, Nozaki M, Morine N, Suzuki N, Nishikawa K, Morgan BP, Matsuo S. 2007. A protein toxin from the sea anemone Phyllodiscus semoni targets the kidney and causes a severe renal injury with predominant glomerular endothelial damage. American Journal of Pathology 171: 402-414.

Nagai H, Oshiro N, Takuwa-Kuroda K, Iwanaga S, Nozaki M, Nakajima T. 2002a. Novel proteinaceous toxins from the nematocyst venom of the Okinawan sea anemone Phyllodiscus semoni Kwietniewski. Biochemical and Biophysical Research Communications 294: 760-763.

Nagai H, Oshiro N, Takuwa-Kuroda K, Iwanaga S, Nozaki M, Nakajima T. 2002b. A new polypeptide toxin from the nematocyst venom of an Okinawan sea anemone Phyllodiscus semoni (Japanese name 'unbachi-isoginchaku'). Bioscience Biotechnology and Biochemistry 66: 2621-2625.

Nagata K, Hide M, Tanaka T, Ishii K, Izawa M, Sairenji T, Tomita K, Shimizu E. 2006. Anaphylactic shock caused by exposure to sea anemones. Allergology International 55: 181-184.

Okuno J. 2002. A new species of the 'Periclimenes aesopius species group' (Decapoda: Palaemonidae: Pontoniinae) from the Ryukyu Islands, Southern Japan. Bulletin of the National Science Museum Series A (Zoology) 28: 211-222.

Okuno J, Bruce AJ. 2010. Designation of Ancylomenes gen. nov., for the 'Periclimenes aesopius species group' (Crustacea: Decapoda: Palaemonidae), with the description of a new species and a checklist of congeneric species. Zootaxa 2372: 85-105.

Oshiro N, Iwanaga S, Nozaki M, Nakasone T, Uchida H. 2001. New distribution record and venom toxicity of the sea anemone Actineria villosa (Quey et Gaimard, 1833). Annual Report of Okinawa Prefectural Institute of Health and Environment 35: 133-136. [in Japanese]

Oshiro N, Kobayashi C, Iwanaga S, Nozaki M, Namikoshi M, Spring J, Nagai H. 2004. A new membrane-attack complex/ perforin (MACPF) domain lethal toxin from the nematocyst venom of the Okinawan sea anemone Actineria villosa. Toxicon 43: 225-228.

Ottaway JR. 1977. Predators of sea anemones. Tuatara 22: 213221.

Plotkin PT, Wicksten MK, Amos AF. 1993. Feeding ecology of the loggerhead sea turtle Caretta caretta in the Northwestern Gulf of Mexico. Marine Biology 115: 1-5.

Porat D, Chadwick-Furman NE. 2004. Effects of anemonefish on giant sea anemones: Expansion behavior, growth and survival. Hydrobiologia 530/531: 513-520.

Quoy JRC, Gaimard P. 1833. Voyage de Découvertes de l'Astrolabe Exécuté par Ordre du Roi, Pendant les Années 18261827-1828-1829, sous le Commandement de M.J. Dumont D’Urville. Paris: J. Tastu.
Reid PJ, Shettleworth SJ. 1992. Detection of cryptic prey: Search image or search rate? Journal of Experimental Psychology: Animal Behavior Processes 18: 273-286.

Reimer JD, Ono S, Fujiwara Y, Takishita K, Tsukahara J. 2004. Reconsidering Zoanthus spp. diversity: molecular evidence of conspecifity within four previously presumed species. Zoological Science 21: 517-525.

Reimer JD, Ono S, Tsukahara J, Iwase F. 2008. Molecular characterization of the zoanthid genus Isaurus (Anthozoa: Hexacorallia) and its zooxanthellae (Symbiodinium spp). Marine Biology 153: 351-363.

Renema W, Hoeksema BW, Van Hinte JE. 2001. Larger benthic foraminifera and their distribution patterns on the Spermonde shelf, South Sulawesi. Zoologische Verhandelingen, Leiden 334: 115-149.

Richardson DL, Harriott VJ, Harrison PL. 1997. Distribution and abundance of giant sea anemones (Actiniaria) in subtropical eastern Australian waters. Marine and Freshwater Research 48: 59-66.

Röding PF. 1798. Museum Boltenianum sive Catalogus cimeliorum e tribus regnis naturae quae olim collegerat Joa. Fried. Bolten M.D. p.d. Pars secunda continens Conchylia sive Testacea univalvia, bivalvia et multivalvia. Hamburg: Johan Christi Trappii.

Ruxton GD, Speed MP, Sherratt TN. 2004. Avoiding Attack. The Evolutionary Ecology of Crypsis, Warning Signals and Mimicry. Oxford: Oxford University Press.

Satoh H, Oshiro N, Iwanaga S, Namikoshi M, Nagai H. 2007. Characterization of PsTX-60B, a new membrane-attack complex/perforin (MACPF) family toxin, from the venomous sea anemone Phyllodiscus semoni. Toxicon 49: 12081210 .

Schenkel E. 1902. Beitrag zur Kenntnis der Dekapodenfauna von Celebes. Verhandlungen der Naturforschenden Gesellschaft in Basel 13: 485-585.

Scott A, Malcolm HA, Damiano C, Richardson DL. 2011. Long-term increases in abundance of anemonefish and their host sea enomones in an Australian marine protected area. Marine and Freshwater Research 62: 187-196.

Skelhorn J, Ruxton GD. 2010. Mimicking multiple models: polyphenetic masqueraders gain additional benefits from crypsis. Behavioral Ecology 22: 60-65.

Skelhorn J, Rowland HM, Ruxton GD. 2010a. The evolution and ecology of masquerade. Biological Journal of the Linnean Society 99: 1-8.

Skelhorn J, Rowland HM, Speed MP, Ruxton GD. 2010b. Masquerade: Camouflage without crypsis. Science 327: 51.

Skelhorn J, Rowland HM, Delf J, Speed MP, Ruxton GD. 2011. Density-dependent predation influences the evolution and behavior of masquerading prey. Proceedings of the National Academy of Sciences of the United States of America 108: 6532-6536.

Solé-Cava AM, Thorpe JP. 1992. Genetic divergence between colour morphs in populations of the common intertidal sea anemones Actinia equina and A. prasina (Anthozoa: Actiniaria) in the Isle of Man. Marine Biology 112: 243-252.

Stefani F, Benzoni F, Yang SY, Pichon M, Galli P, Chen CA. 2011. Comparison of morphological and genetic analyses reveals cryptic divergence and morphological plasticity in Stylophora (Cnidaria, Scleractinia). Coral Reefs, doi: 10.1007/s00338-011-0797-4. 
Stoletzki N, Schierwater B. 2005. Genetic and color morph differentiation in the Caribbean sea anemone Condylactis gigantea. Marine Biology 147: 747-754.

Strack HL. 1993. Results of the Rumphius Biohistorical Expedition to Ambon (1990). Part 1. General account and list of stations. Zoologische Verhandelingen, Leiden 289: 1-72.

Tixier-Durivault A. 1970. Les octocoralliaires de Nouvelle-Caledonie. L'Expedition francaise sur les recifs coralliens de la Nouvelle-Caledonie organisee sous l'egide de la fondation Singer-Polignac 1960-1963, 4: 171-350. Paris: Editions de la Foundation Singer-Polignac.

Todd P. 2008. Morphological plasticity in scleractinian corals. Biological Reviews 83: 315-337.

Tomas J, Aznar FJ, Raga JA. 2001. Feeding ecology of the loggerhead turtle Caretta caretta in the western Mediterranean. Journal of Zoology, London 255: 525-532.

Uchida H. 2001. Sea Anemones in Japanese waters. TBS Britannica. Tokyo. [in Japanese]

Uechi G, Toma H, Arakawa T, Sato Y. 2005a. Biochemical and physiological analyses of a hemolytic toxin isolated from a sea anemone Actineria villosa. Toxicon 45: 761-766.

Uechi G, Toma H, Arakawa T, Sato Y. 2005b. Molecular cloning and functional expression of hemolysin from the sea anemone Actineria villosa. Protein Expression and Purification 40: 379-384.

Utinomi H. 1951. Asterospicularia laurae n. gen. et n. sp., the type of a new family of alcyonarians with setellate spicules. Pacific Science 5: 190-196.

Van Nierop MM, den Hartog JC. 1984. A study on the gut contents of live juvenile loggerhead turtles, Caretta caretta (Linnaeus) (Reptilia, Cheloniidae), from the south-eastern part of the North Atlantic Ocean, with emphasis on coelenterate identification. Zoologische Mededelingen, Leiden 59: 35-54.
Van Ofwegen, LP. 2008. The genus Sinularia (Octocorallia: Alcyonacea) at Palau, Micronesia. Zoologische Medelingen, Leiden 82: 631-735.

Veron JEN. 2000. Corals of the World. Townsville: Australian Institute of Marine Science.

Watts PC, Allcock AL, Lynch SM, Thorpe JP. 2000. An analysis of the nematocysts of the beadlet anemone Actinia equi$n a$ and the green sea anemone Actinia prasina. Journal of the Marine Biological Association of the United Kingdom 80: 719-724.

Weinland DF. 1860. Über Inselbildung durch Korallen und Mangrovebüsche im mexikanischen Golf. Württembergische Naturwissenschaftliche Jahreshefte 16: 31-44.

Whitaker K. 2006. Genetic evidence for mixed modes of reproduction in the coral Pocillopora damicornis and its effect on population genetics. Marine Ecology Progress Series 306: 115-124.

Williamson JA, Fenner PJ, Burnett JW, Rifkin JF. 1996. Venomous and poisonous marine animals: A medical and biological handbook. Sydney: University of New South Wales Press.

Yoshiyama RM, Wallace WD, Burns JL, Knowlton AL, Welter JR. 1996. Laboratory food choice by the mosshead sculpin, Clinocottus globiceps (Girard) (Teleostei; Cottidae), a predator of sea anemones. Journal of Experimental Marine Biology and Ecology 204: 23-42.

Received: 13 April 2011

Revised and accepted: 2 September 2011

Published online: 18 October 2011

Editor: R.W.M. van Soest 